\title{
Risk Perception and Hesitancy Toward COVID-I9 Vaccination Among Healthcare Workers and Staff at a Medical College in Nepal
}

\author{
Sabita Paudel (iD' \\ Subish Palaian (iD) 2,3 \\ Pathiyil Ravi Shankar (iD) 4 \\ Nuwadatta Subedi (D) \\ 'Department of Pharmacology, Gandaki \\ Medical College, Pokhara, Gandaki, \\ Nepal; ${ }^{2}$ Department of Clinical Sciences, \\ College of Pharmacy and Health Sciences, \\ Ajman University, Ajman, United Arab \\ Emirates; ${ }^{3}$ Center of Medical and Bio- \\ Allied Health Sciences Research, Ajman \\ University, Ajman, United Arab Emirates; \\ ${ }^{4}$ IMU Center for Education, International \\ Medical University, Bukit Jalil, Kuala \\ Lumpur, Malaysia; ${ }^{5}$ Department of \\ Forensic Medicine, Gandaki Medical \\ College, Pokhara, Gandaki, Nepal
}

Correspondence: Sabita Paudel

Gandaki Medical College, Rithepani,

Pokhara, Gandaki, Nepal

Tel +977 $61538595,550253,534657$

$\mathrm{Fax}+97761550254$

Email drsabitapaudel@gmail.com
Purpose: The study was conducted to explore the perception of healthcare workers and staff towards the risk of COVID-19 vaccination and to study vaccine hesitancy amongst them.

Methods: A total of 266 healthcare workers working in a medical college in Nepal were studied using a questionnaire consisting of three sections: demographics, experiences and perception of COVID-19, and COVID-19 vaccine safety. Data were analyzed using IBM SPSS version 26. The total perception score was calculated by noting respondent's agreement with a set of eleven statements using a Likert-type scale. Non-parametric tests (MannWhitney U and Kruskal-Wallis) were used for analysis $(\mathrm{p}<0.05)$.

Results: Altogether, $13.9 \%$ of respondents had been diagnosed COVID-19 positive prior to the survey. Many considered themselves to be at increased risk of contracting COVID-19. Only over one third (38.3\%) were willing to be vaccinated. The most common reason for refusal/hesitancy was concern about vaccine safety. The median (interquartile range) total perception score was 36 (4) (maximum possible score=55). The score was significantly higher among those who had been diagnosed COVID positive, those who perceived the pandemic as being moderate or severe and among those willing to be vaccinated

Conclusion: Addressing doubts related to vaccine safety and providing more data on the safety of vaccine may be helpful in overcoming hesitancy.

Keywords: knowledge score, nonparametric tests, staff, questionnaire

\section{Introduction}

Coronavirus disease 2019 (COVID-19) is still creating havoc globally. According to a report of the WHO on May 26, 2021, there were 3,482,907 deaths and $167,492,769$ confirmed cases worldwide. ${ }^{1}$ Since the start of the pandemic in December $2019{ }^{2}$, several pharmacological and nonpharmacological solutions have been tested with limited benefits. ${ }^{3}$ Multiple vaccines against the virus have now been produced. ${ }^{4}$ Vaccines could be the best option to prevent the disease from spreading, with more virulent mutant strains being constantly identified. Presently, some vaccines are already on the Emergency Use Listing, whereas some are awaiting approval. ${ }^{5}$

Since healthcare workers are directly involved in diagnosing, treating, and taking care of patients, they are at high risk of infection. ${ }^{6}$ Most countries have started their vaccination programs. Vaccination has been shown to be effective (to a varying extent) in reducing the severity of complications. ${ }^{7,8}$ According to a study, $70 \%$ of the population should be vaccinated to attain herd immunity. ${ }^{9}$ There are 
vaccine skeptics, for both $\mathrm{H} 1 \mathrm{~N} 1{ }^{10}$ and COVID-19, ${ }^{11}$ who can hinder vaccination by creating and spreading speculations. Acceptance of misguided information regarding the COVID-19 vaccine by the public is likely to create hesitancy among the public to be vaccinated. ${ }^{12}$ There are a large number and types of vaccines available with different storage and distribution logistics and possible adverse effects, which can create confusion among the public.

In Nepal, there were 535,525 confirmed cases and 6845 deaths, according to the report of John Hopkins University of Medicine on May 23, 2021. ${ }^{13}$ Nepal has initiated vaccination of healthcare workers and frontliners on January 27, 2021, with COVISHIELD vaccine from Oxford/AstraZeneca manufactured in the neighboring country, India. ${ }^{14}$ The efficacy of this vaccine is reported to be $63.09 \%$ against symptomatic COVID-19 infection. ${ }^{15}$ In a medical college, different categories of staff work include healthcare workers involved directly in the management of COVID-19 patients and staff working in academic and managerial roles who are not directly involved in patient management. Nonetheless, they may have an essential role in communicating to the public regarding vaccines as it is very likely that they may be approached for information. Studies have mainly focused on the overall perception of COVID-19 and acceptance of vaccines. $^{16,17}$ To date, the perception of the Nepalese population toward the safety of the COVID-19 vaccine has not been documented. The study conducted by Barry et al revealed that healthcare workers who believed in the safety of the vaccine and regarded the vaccine as a means to stop the spread of an illness were more willing to be vaccinated. ${ }^{17}$

Information regarding the perception of vaccines among staff working in a medical college would be beneficial for the institution to design appropriate educational programs. Studies focusing on the perception of vaccine safety are few, so this study can be a valuable addition to the literature. This study also provides an opportunity to compare perceptions of vaccine safety among different countries. Understanding healthcare workers' perceptions on vaccine safety can enable governments to institute appropriate early strategies to improve vaccination rates among the public. Hence, the present study was conducted to assess the safety concerns and reasons for vaccine hesitancy among medical and nonmedical staff at a medical college in Nepal.

\section{Method}

\section{Study Design}

A cross-sectional descriptive study was conducted among healthcare workers and staff of a medical college.

\section{Ethical Approval}

Ethical approval was obtained from the Institutional Review Committee of Gandaki Medical College with the approval number 94/77/78 dated January 25, 2021. This study was conducted following the Declaration of Helsinki.

\section{Informed Consent and Confidentiality}

The respondents were provided with a written summary regarding the research and contact information of the principal investigator. They were assured of the confidentiality of the information collected, and written informed consent was obtained. Among respondents completing the survey online, information was provided at the beginning of the form, and consent was obtained online.

\section{Study Site}

The study was conducted at a medical college. A total of 800 employees working at various levels such as general workers, paramedics, medical doctors, and academic faculties were invited to participate.

\section{Study Timing}

The data collection was performed between January 27 and February 3, 2021.

\section{Study Tool}

\section{Questionnaire Content}

COVID-19 vaccine safety questionnaire was developed on the basis of the information obtained from previous studies. $^{10,18-22}$ The questionnaire had three sections: Section 1, demographics; Section 2, experiences and perception of COVID-19; and Section 3, vaccine safety (Supplementary File 1). Questions were divided into five themes of experience of COVID-19: choice of vaccine, willingness to be vaccinated, perception on efficacy and safety of the vaccine, information on vaccine safety, and trust in vaccine producers. There were three to five questions in each theme.

\section{Questionnaire Validation}

The face validation was performed by a clinical faculty, and his suggestions were incorporated. He examined the sequence of questions, number of questions, any 
ambiguity, and grammatical errors. Construct and content validation of the questionnaire were performed by two pharmacology experts from Nepal working in two different extramural institutions.

\section{Reliability Testing}

The questionnaire was pilot tested among 30 respondents not participating in the study. The Cronbach's alpha value obtained was 0.76 .

\section{Inclusion and Exclusion Criteria}

Adults aged $>18$ years working at the study site who provided consent were included. Staff who were already vaccinated were excluded because the response to a few questions may be biased if answered by vaccinated individuals.

\section{Sample Size Calculation}

Being a descriptive survey, the sample size was calculated as per Cochran's formula:

$\mathrm{N}=\mathrm{Z}^{2} \mathrm{pq} / \mathrm{e}^{2}$

$\mathrm{Z}=$ value is obtained from $\mathrm{Z}$ table at a given value of precision, 1.96

$\mathrm{p}=$ estimated proportion of the population which has the attribute in question; for our heterogeneous group of population, we assumed greater variability of $50 \%$, so $p=0.5$

$\mathrm{q}=1-\mathrm{p}=1-0.5=0.5$

$\mathrm{e}=$ desired level of precision (ie, the margin of error) $=$ $5 \%=0.05$

- Including these values in the formula

$\mathrm{N}=1.96^{2} * 0.5 * 0.5 / 0.05^{2}$

$\mathrm{N}=384.16$

Although the calculated sample size was 384, the authors could only obtain responses from 266 respondents.

\section{Sampling Method and Stratification}

Samples were obtained from different clusters of the population such as managerial and administrative staff, nurses, faculties, medical doctors and postgraduate residents, and general workers in a proportionate manner. We further divided these clusters on the basis of their gender.

\section{Data Collection}

The questionnaire was self-administered (using either online or printed form) to 211 respondents; however, for 55 respondents who could not interpret the questionnaire properly, data were collected through interviews. The interviewers were trained data collectors. They were trained by one of the coinvestigators on interviewing, communicating with respondents, and completing the form. Demographic details of all staff were obtained from the administration of the college. Questionnaires were sent using an online form to the ones whose email address/messenger account could be accessed (55 samples) and who could complete the questionnaire online. For the rest, questionnaires were administered in printed form in English to those who could comprehend English and in Nepali to those who could only comprehend Nepali.

\section{Data Analysis}

The completed questionnaires were coded, entered, and analyzed using IBM SPSS version 21.0. Information regarding the respondents' gender, age, monthly income, which category of staff they belong to, whether they or their family members staying with them had been diagnosed to be COVID positive, their perception about the severity of the pandemic, whether they perceived themselves to be at increased risk of contracting COVID-19 and hence at priority for receiving the vaccine, and their willingness to be vaccinated were collected. These data were analyzed descriptively.

The total perception score about COVID-19 vaccines was calculated by noting the respondents' agreement with a set of 11 statements using a Likert-type scale. The scores of certain statements were reversed while calculating the total score. The normality of the distribution of the score was checked using the one-sample Kolmogorov-Smirnov test $(\mathrm{p}<0.05)$. As the total score was not normally distributed (one-sample Kolmogorov-Smirnov test), nonparametric tests (Mann-Whitney $U$ and Kruskal-Wallis) were used for analysis $(\mathrm{p}<0.05)$. The average scores among different subgroups of respondents were compared using appropriate statistical tests $(\mathrm{p}<0.05)$. Post hoc comparisons were conducted where appropriate.

\section{Results}

A total of 266 respondents (out of 384 calculated sample size representing a response rate of $69.27 \%$ ) participated in the survey. The distribution according to categories of staff and gender was not significantly different in the sample when compared with the population.

Table 1 shows the demographic characteristics of the study respondents. The majority of the population were healthcare workers. Nursing staff and general workers were the most common categories. 
Table I Demographic Characteristics of Study Respondents

\begin{tabular}{|c|c|}
\hline Characteristics & $\begin{array}{l}\text { Number } \\
\text { (Percentage) }\end{array}$ \\
\hline $\begin{array}{l}\text { Gender } \\
\text { Female } \\
\text { Male }\end{array}$ & $\begin{array}{l}190(71.4) \\
76(28.6)\end{array}$ \\
\hline $\begin{array}{l}\text { Age (in years) } \\
20-30 \\
30-40 \\
40-50 \\
50-60 \\
\text { Missing }\end{array}$ & $\begin{array}{l}122(45.9) \\
78(29.3) \\
33(12.4) \\
19(7.1) \\
14(5.3)\end{array}$ \\
\hline $\begin{array}{l}\text { Monthly income (NPR) } \\
\text { Up to } 13,450 \\
13,450-30,000 \\
30,000-60,000 \\
\text { Greater than } 60,000 \\
\text { Missing } \\
\text { Education level }\end{array}$ & $\begin{array}{l}45(16.9) \\
169(63.5) \\
16(6.0) \\
35(13.4) \\
1(0.4)\end{array}$ \\
\hline $\begin{array}{l}\text { Secondary } \\
\text { High school } \\
\text { Graduate } \\
\text { Postgraduate } \\
\text { Missing }\end{array}$ & $\begin{array}{l}59(22.2) \\
105(39.5) \\
43(16.2) \\
56(21.1) \\
3(1.1)\end{array}$ \\
\hline $\begin{array}{l}\text { Profession } \\
\text { Healthcare worker } \\
\text { Non healthcare worker }\end{array}$ & $\begin{array}{l}189(71.1) \\
77(28.9)\end{array}$ \\
\hline $\begin{array}{l}\text { Designation } \\
\text { Managerial and admin staff } \\
\text { Faculty } \\
\text { Medical and dental officers, } \\
\text { postgraduates } \\
\text { Nursing staff } \\
\text { General worker } \\
\text { Paramedic } \\
\text { Missing }\end{array}$ & $\begin{array}{l}13(4.9) \\
49(18.4) \\
17(6.4) \\
81(30.5) \\
66(24.8) \\
39(14.7) \\
1(0.4)\end{array}$ \\
\hline
\end{tabular}

Table 2 depicts that few respondents $(13.9 \%$; $n=37)$ had been diagnosed as COVID-19 positive, whereas $24(9 \%)$ had their family members staying with them diagnosed as COVID-19 positive. One hundred and forty-eight respondents were either extremely concerned or quite concerned about themselves or their family members contracting COVID-19. Many considered themselves at increased risk of contracting COVID-19 because of increased contact with the public and patients due to the nature of their job. Two hundred and twenty respondents $(82.7 \%)$ perceived the severity of the pandemic to be moderate or severe.
Table 2 COVID-I9 Related Information of the Respondents

\begin{tabular}{|l|l|}
\hline Characteristics & $\begin{array}{l}\text { Number } \\
\text { (Percentage) }\end{array}$ \\
\hline Have you been diagnosed to be COVID-19 & \\
positive? & $37(13.9)$ \\
Yes & $229(86.1)$ \\
No & \\
\hline Have any of your family members staying with & \\
you been diagnosed COVID-19 positive? & $24(9.0)$ \\
Yes & $240(89.5)$ \\
No & $2(0.8)$ \\
Missing & \\
\hline How concerned are you about you or your & \\
family member contracting COVID-19? & $74(27.8)$ \\
Extremely concerned & $74(27.8)$ \\
Quite concerned & $89(33.5)$ \\
Little concerned & $29(10.9)$ \\
Not concerned & $60(33.8)$ \\
\hline Do you identify yourself to be at increased risk & \\
for COVID-19? & $130(48.9)$ \\
Yes & $159(59.7)$ \\
No & $101(38.0)$ \\
Do not know & $6(2.3)$ \\
\hline Reason why you consider yourself at higher risk & \\
Comorbid illness & $17(6.4)$ \\
Old age & $8(3.0)$ \\
Increased contact with public due to nature of & $136(51.1)$ \\
job & \\
Provided care to family member who was & \\
suffering from COVID & $(6.4)$ \\
Smoker & \\
Obese & \\
Pregnancy & \\
Others & \\
\hline Perception about severity of the pandemic & \\
Mild & \\
Moderate & \\
\hline Missing & \\
\hline
\end{tabular}

Regarding being eligible to receive the vaccine on priority (Table 3), 164 respondents thought they were eligible as they were healthcare workers and had frequent contact with patients who could be COVID-19 positive. One hundred and two respondents (38.3\%) were willing to be vaccinated. The most common reason for vaccine refusal/hesitancy was concern about vaccine safety.

The median total perception score was 36 , and the interquartile range was 4 . The maximum possible score 
Table 3 Respondents' Opinion About COVID-19 Vaccination

\begin{tabular}{|c|c|}
\hline Characteristics & $\begin{array}{l}\text { Number } \\
\text { (Percentage) }\end{array}$ \\
\hline \multicolumn{2}{|l|}{$\begin{array}{l}\text { Do you think you are eligible to receive the } \\
\text { vaccine on priority? }\end{array}$} \\
\hline Yes & 164 (6I.7) \\
\hline No & $63(23.7)$ \\
\hline Do not know & $35(13.2)$ \\
\hline Missing & $4(1.5)$ \\
\hline \multicolumn{2}{|l|}{ Reason why you think you are eligible } \\
\hline Comorbid illness & $21(7.9)$ \\
\hline Old age & $7(2.6)$ \\
\hline Healthcare worker & $93(35.0)$ \\
\hline High contact with COVID-19 patients & $78(29.3)$ \\
\hline \multicolumn{2}{|l|}{$\begin{array}{l}\text { Are you willing to be vaccinated if the vaccine is } \\
\text { offered to you? }\end{array}$} \\
\hline Yes & $102(38.3)$ \\
\hline No & $90(33.8)$ \\
\hline Undecided & $17(6.4)$ \\
\hline If there are less adverse effects & $55(20.7)$ \\
\hline \multicolumn{2}{|l|}{ Reasons for refusal } \\
\hline Vaccine is not necessary for me & $6(2.3)$ \\
\hline I am concerned about vaccine safety & $40(15.0)$ \\
\hline I do not have belief in vaccination & $15(5.6)$ \\
\hline I have already been infected with COVID-I9 & $12(4.5)$ \\
\hline Others & $17(6.4)$ \\
\hline \multicolumn{2}{|l|}{$\begin{array}{l}\text { How concerned will you be if vaccine is not } \\
\text { offered to you? }\end{array}$} \\
\hline Extremely concerned & $46(17.3)$ \\
\hline Quite concerned & $63(23.7)$ \\
\hline Little/no concerned & $72(27.1)$ \\
\hline Do not know & $23(19.5)$ \\
\hline Missing & $10(3.8)$ \\
\hline
\end{tabular}

was 55. Table 4 shows median perception scores that were significantly different among subgroups of respondents. The scores were significantly higher among males, those with a higher monthly income, those with postgraduate education, among medical and dental officers, postgraduates, and managerial and administrative staff. The score was also significantly higher among those who had been diagnosed as COVID positive, those who perceived the pandemic as being moderate or severe in intensity, and those who were willing to be vaccinated.

On conducting pairwise comparisons, the scores were significantly different among those with a monthly income of up to 13,450 Nepalese rupees ( 1 Nepalese rupee $=0.0084$ US dollars), those with a monthly income of more than 60,000
Table 4 Median Perception Scores Which Were Significantly Different Among Subgroups of Respondents

\begin{tabular}{|c|c|c|}
\hline Characteristics & $\begin{array}{l}\text { Median } \\
\text { Score }\end{array}$ & $P$ value \\
\hline $\begin{array}{l}\text { Gender } \\
\text { Male } \\
\text { Female }\end{array}$ & $\begin{array}{l}37 \\
35\end{array}$ & 0.003 \\
\hline $\begin{array}{l}\text { Income (Nepalese rupees) } \\
\text { Less than } 13,450 \\
13,450-30,000 \\
30,000-60,000 \\
\text { Greater than } 60,000 \\
\text { Pairwise comparison } \\
\text { Up to } 13,450 \text { per month-More than } 60,000 \\
\text { NPR per month } \\
\text { 13,450-30,000 NPR per month-More than } \\
60,000 \text { NPR per month }\end{array}$ & $\begin{array}{l}35 \\
35 \\
37 \\
38\end{array}$ & 0.046 \\
\hline $\begin{array}{l}\text { Level of education } \\
\text { Secondary } \\
\text { High school } \\
\text { Graduate } \\
\text { Postgraduate } \\
\text { Pairwise comparison } \\
\text { High school- PG and above }\end{array}$ & $\begin{array}{l}36 \\
35 \\
36 \\
37.5\end{array}$ & 0.003 \\
\hline $\begin{array}{l}\text { Designation } \\
\text { Managerial and admin staff } \\
\text { Faculty } \\
\text { Medical and dental officers, postgraduates } \\
\text { Nursing staff } \\
\text { General worker } \\
\text { Paramedic }\end{array}$ & $\begin{array}{l}37 \\
36 \\
37 \\
35 \\
35 \\
36\end{array}$ & 0.016 \\
\hline $\begin{array}{l}\text { Pairwise comparison } \\
\text { Nursing staff- Faculty }\end{array}$ & & 0.04 \\
\hline $\begin{array}{l}\text { Have any of your family members staying } \\
\text { with you been diagnosed to be COVID-19 } \\
\text { positive? } \\
\text { Yes } \\
\text { No }\end{array}$ & $\begin{array}{l}36.5 \\
35\end{array}$ & 0.037 \\
\hline $\begin{array}{l}\text { Perception about severity of the pandemic } \\
\text { Mild } \\
\text { Moderate } \\
\text { Severe }\end{array}$ & $\begin{array}{l}34 \\
35 \\
36\end{array}$ & 0.042 \\
\hline $\begin{array}{l}\text { Pairwise comparison } \\
\text { Mild-severe }\end{array}$ & & 0.037 \\
\hline $\begin{array}{l}\text { Are you willing to be vaccinated if the vaccine } \\
\text { is offered to you? } \\
\text { Yes } \\
\text { No } \\
\text { Undecided }\end{array}$ & $\begin{array}{l}37 \\
34 \\
36\end{array}$ & $<0.001$ \\
\hline
\end{tabular}


Nepalese rupees, and those with a monthly income of 13,450-30,000 and more than 60,000 Nepalese rupees. They were significantly different among those with high school education and postgraduate education. Scores were significantly higher among faculty than among nursing staff. Those who perceived the pandemic as severe had significantly higher scores compared with those who perceived it as mild.

\section{Discussion}

History has shown that in many instances, vaccines can save millions of lives, ${ }^{23}$ and the same hope continues for the present pandemic. Presently, more than a dozen COVID-19 vaccines are under development. ${ }^{24,25}$ As COVID-19 vaccines are being rolled out, countries have prioritized frontline healthcare workers as candidates for vaccination. ${ }^{26-29}$ Perception of healthcare workers can strongly influence the general public's opinion on vaccination. This is also true in Nepal where healthcare workers, especially medical doctors, are well respected ${ }^{30}$ and considered as the final authority on health-related issues and medicines. Since COVID-19 vaccines were approved quickly and vaccine development phases were quickened, one cannot ignore the public's legitimate concerns regarding safety, especially those related to long-term adverse effects. Reports from several countries have documented safety concerns regarding COVID-19 vaccines among all groups of people, including college students, ${ }^{31}$ healthcare workers, ${ }^{32}$ and the general public. ${ }^{33}$

Healthcare workers who were directly involved in the care of COVID patients were willing to be vaccinated, whereas parents, nurses, and healthcare workers who were not directly involved were reluctant to do so. ${ }^{34}$ In another study, medical students who were not willing to be vaccinated were concerned about the adverse reactions after vaccination. ${ }^{35}$ Presently, the reported ADRs due to COVID-19 vaccines are mild, ${ }^{36}$ although there have been newspaper reports on vaccine-associated deaths. ${ }^{37}$ Conversely, there is no option other than vaccination, as there are no proven drugs for the cure of COVID-19 at this point.

In the present study, slightly over one-tenth of the respondents considered themselves not eligible for COVID-19 vaccination. As per the current evidence, the COVID-19 vaccine cannot be given to individuals aged $<16$ years and to those with previous allergies to any vaccine. ${ }^{38}$ Consumers should be educated about their eligibility for COVID-19 vaccines, and the eligibility criteria should be widely publicized to increase public acceptance.
There is a need for guidelines in vaccinating people who are not considered eligible to receive the vaccination as some of them may be high-risk individuals.

Of the respondents, $61.7 \%$ considered themselves to be a priority group for receiving the vaccination. The major reasons mentioned were being healthcare workers and having frequent contact with COVID-19 patients. Currently, the Nepal government prioritizes frontline workers and elderly people living in care homes as a priority group for COVID19 vaccination. ${ }^{39}$ Each country must analyze the morbidity and mortality pattern due to COVID-19 and make their own priority listing for COVID-19 vaccine because of the possible delay in supply of vaccines for the entire population.

Although the healthcare workers in the present study knew that they were a priority group for vaccination, their willingness to be vaccinated was not high. The situation can be even worse in the case of the public. Contrary to our findings, in China, $91.3 \%$ of the adult population were willing to be vaccinated. ${ }^{33}$ But in the United States, a study conducted among adult people showed that only 57.6\% were inclined toward vaccination. ${ }^{40}$ Poor vaccination acceptance can prolong the pandemic, and hence, it is recommended to conduct educational programs focusing on the safety, benefits, and efficacy of COVID-19 vaccines. ${ }^{41}$ A newspaper article described the recent status of vaccine hesitancy among the Nepalese population and urged immediate measures for tackling this issue. ${ }^{42}$ So far, no visible approach to public education has been noted in the country, and the responsibility lies in the hands of the drug regulatory authority and health ministry, social organizations, pharmacy and other medical organizations, and individual researchers to immediately devise and implement strategies to promote vaccine acceptance among the public.

The reasons for the refusal of vaccination were predominantly related to "the safety of the vaccine." The present study findings are different from those reported by a US study conducted among the adult population in which demography, knowledge, and politics had an influence on vaccination. ${ }^{43}$ Although the present study involved staff at a medical college, the comparison clearly demonstrates multiple factors that contribute to vaccine hesitancy, which must be further investigated.

Among the respondents, males had higher perception scores regarding COVID-19 vaccines. In a US study conducted among the adult population, males were more willing to be vaccinated than were females. ${ }^{43}$ In a similar study conducted among healthcare workers in Saudi Arabia, males were 1.55 times more willing than were 
females to be vaccinated. ${ }^{17}$ It is also documented that males are more vulnerable to severe disease and mortality probably because the testes harbor the virus and delay viral clearance. ${ }^{44}$ The increased scores among males in the present study could also be influenced by internet usage and the fact that information sources were more easily available for males than for females.

The educational status of health professionals had a significant impact on perceptions that are related to COVID-19 vaccine safety. Education is well understood to influence self-care behavior, ${ }^{45}$ medication intake, ${ }^{46}$, and safety precautions. ${ }^{47}$ Moreover, more qualified medical practitioners and other healthcare workers directly involved in patient care are more likely to have better perceptions compared with staff working in other areas.

Staying with family members who were COVID-19 positive was found to influence the scores of respondents. While staying with a family member with COVID-19, one must practice social distancing and should provide for the basic needs of the patient such as medications and adequate intake of fluids and watch for warning signs of deterioration. ${ }^{48}$ During this process, a family member is expected to gain more knowledge about the disease, its treatment options, and vaccination.

A major problem seen with COVID-19 is that at least during the early stage of the pandemic, many believed it was a simple problem that required not much attention. ${ }^{49}$ This attitude had probably accelerated the pandemic progression in several parts of the world. In the present research, respondents who believed that the pandemic was severe had a significantly higher perception score. At the time of the study, with the pandemic causing significant global disruption, most were aware of its severity.

The limitation was that some of the nurses and paramedics who were involved in vaccination were trained by a government agency before commencing the vaccination, which might have influenced their choices for vaccination. Of the 385 calculated sample sizes, authors could only obtain the responses of 266 because the date of data collection coincided with the day of vaccination announced by the Nepal government.

\section{Conclusion}

Although a high number of healthcare workers considered themselves as a priority group for COVID-19 vaccination, one-third of them were not willing to be vaccinated mainly because of safety concerns. Healthcare workers not willing to take the vaccine had poor perception scores, which suggests the need to strengthen knowledge to improve vaccination.

\section{Acknowledgments}

The authors thank all the respondents who spent their valuable time in completing the study questionnaire. Special thanks are due to the administration of Gandaki Medical College for providing the researchers with logistical support. The assistance offered by Mr. Dinesh Paudel in providing the demographic data for all staff and further stratification of samples is highly appreciated. The authors also thank Dr. Dipendra Kandel, Dr. Aakash Chudal, Dr. Gyaltsen Dolpo, Dr. Umesh Shrestha, Dr. Vipul Bhusan Mallik, Dr. Ankur KC, Ms. Nanda Gurung, Ms. Prem Kumari Chhettri, Ms. Sabitri Poudel, and Krishna Paudel for assisting in data collection. The authors thank Dr. Nisha Jha, KIST Medical College, Kathmandu, Nepal, and Dr. Mukhtar Ansari, College of Pharmacy, Hail University, Saudi Arabia, for their help in the content validation of the study questionnaire. The authors would like to thank Enago (www.enago.com) for the English language review. Authors would also like to acknowledge the Ajman University for providing $50 \%$ processing fee for this manuscript.

\section{Disclosure}

There are no conflicts of interest to declare, and the authors have received no funding to conduct this research.

\section{References}

1. World Health Organization. WHO Coronavirus (Covid 19) Dashboard. Available from: https://covid19. who.int/?gclid= Cj0KCQjwhr2FBhDbARIsACjwLo2dj08QXZ1qxHhfL3mvALILY6v TWpuYoHsC6VUqZnsc8iOmzMt5I1MaAloKEALw_wcB. Accessed May 27, 2021.

2. Zhu N, Zhang D, Wang W, et al. A novel coronavirus from patients with pneumonia in China 2019. N Engl J Med. 2020;382(8):727-733. doi:10.1056/NEJMoa2001017

3. Sanders JM, Monogue ML, Jodlowski TZ, Cutrell JB. Pharmacologic Treatments for Coronavirus Disease 2019 (COVID-19): a Review. JAMA. 2020;323(18):1824-1836. doi:10.1001/jama.2020.6019

4. COVID 19 vaccines. [homepage on the Internet]. Available from: https://www.who.int/emergencies/diseases/novel-coronavirus-2019/ covid-19-vaccines. Accessed February 20, 2021.

5. Coronavirus Vaccine Tracker. [homepage on the Internet]. Available from: https://www.nytimes.com/interactive/2020/science/coronavirusvaccine-tracker.html. Accessed February 20, 2021.

6. Ali S, Noreen S, Farooq I, Bugshan A, Vohra F. Risk assessment of healthcare workers at the frontline against COVID-19. Pak J Med Sci. 2020;36:99-103. doi:10.12669/pjms.36.COVID19-S4.2790

7. Centers for Disease Control and Prevention. [homepage on the Internet] Benefits of Getting a COVID-19 Vaccine. Available from: https://www.cdc.gov/coronavirus/2019-ncov/vaccines/vaccinebenefits.html. Accessed February 23, 2021.

8. Nature. [homepage on the Internet] COVID research updates: just one dose of vaccine protects against silent COVID infection; 2021. Available from: https://www.nature.com/articles/d41586-020-00502w. Accessed March 4, 2021. 
9. D'souza G, Dowdy D What is Herd Immunity and How Can We Achieve It With COVID-19? COVID 19 School of Public Health Expert insights. John Hopkins Bloomberg School of Public Health; 2021. Available from: https://www.jhsph.edu/covid-19/articles/achiev ing-herd-immunity-with-covid19.html. Accessed April 14, 2021.

10. Eastwood K, Durrheim DN, Jones A, Butler M. Acceptance of pandemic (H1N1) 2009 influenza vaccination by the Australian public. Med $J$ Aust. 2010;192(1):33-36. doi:10.5694/j.13265377.2010.tb03399.x

11. Harapan H, Wagner AL, Yufika A, et al. Acceptance of a COVID-19 Vaccine in Southeast Asia: a Cross-Sectional Study in Indonesia. Front Public Health. 2020;8(381):1-8. doi:10.3389/fpubh.2020.00381

12. Su Z, Wen J, Abbas J, et al. A race for a better understanding of COVID-19 vaccine non-adopters. Brain Behav Immun Health. 2020;9:100159.

13. John Hopkins University of Medicine. Coronavirus resource center. Available from: https://coronavirus.jhu.edu/region/nepal. Accessed May 27, 2021.

14. Government of Nepal, Ministry of Health and Population. [homepage on the Internet] Queries about COVID 19 vaccine by the public. Available from: https://www.mohp.gov.np/eng/news/news. Accessed March 4, 2021.

15. World Health Organisation. The Oxford/AstraZeneca COVID-19 vaccine: what you need to know. Available from: https://www.who. $\mathrm{int} /$ news-room/feature-stories/detail/the-oxford-astrazeneca-covid-19vaccine-what-you-need-to-know\#: :text=How\%20efficacious $\% 20$ is $\% 20$ the $\% 20$ vaccine, associated $\% 20$ with $\% 20$ greater $\% 20$ vaccine $\%$ 20efficacy. Accessed April 14, 2021.

16. Nepal R, Sapkota K, Paudel P, et al. Knowledge, attitude and practice regarding COVID-19 among healthcare workers in Chitwan, Nepal. J Chitwan Med College. 2020;10(33):98-102. doi:10.3126/jcmc. v10i3.32064

17. Barry M, Temsah MH, Alhuzaimi A, et al. COVID-19 vaccine confidence and hesitancy among healthcare workers: a cross-sectional survey from a MERS-CoV experienced nation. medRxiv Prepr 2020. Available from: https://www.medrxiv.org/con tent/10.1101/2020.12.09.20246447v1. Accessed February 20, 2021.

18. Lazarus JV, Ratzan SC, Palayew A, et al. A global survey of potential acceptance of a COVID-19 vaccine. Nat Med. 2021;27(2):225-228. doi:10.1038/s41591-020-1124-9

19. World Health Organization. SAGE working group dealing with vaccine hesitancy (March 2012 to November 2014). Available from: https://www.who.int/immunization/sage/sage_wg_vaccine_hesi tancy_apr12/en/. Accessed March 4, 2021.

20. Al-Mohaithef M, Padhi BK. Determinants of COVID-19 Vaccine Acceptance in Saudi Arabia: a Web-Based National Survey. $J$ Multidiscip Healthc. 2020;13:1657-1663. doi:10.2147/JMDH. S276771

21. World Health Organization. [homepage on the Internet] Vaccine Hesitancy Survey Questions Related to SAGE Vaccine Hesitancy Matrix. Available from: https://www.who.int/immunization/programmes_systems/Survey_ Questions_Hesitancy.pdf. Accessed February 4, 2021.

22. Larson HJ, Jarrett C, Eckersberger E, Smith DM, Paterson P. Understanding vaccine hesitancy around vaccines and vaccination from a global perspective: a systematic review of published literature, 2007-2012. Vaccine. 2014;32(19):2150-2159. doi:10.1016/j. vaccine.2014.01.081

23. Iwasaki A, Omer SB. Why and how vaccines work. Cell. 2020;183 (2):290-295. doi:10.1016/j.cell.2020.09.040

24. Le TT, Andreadakis Z, Kumar A, et al. The COVID-19 vaccine development landscape. Nat Rev Drug Discov. 2020;19(5):305-306. doi:10.1038/d41573-020-00151-8

25. Krause PR, Gruber MF. Emergency use authorization of Covid vaccines-safety and efficacy follow-up considerations. $N$ Engl $J$ Med. 2020;383(19):e107. doi:10.1056/NEJMp2031373
26. Government of UK. [homepage on the Internet] The most vulnerable and health and care workers offered COVID-19 jab as government hits target to protect those most at risk. Available from: https://www. gov.uk/government/news/the-most-vulnerable-and-health-and-careworkers-offered-covid-19-jab-as-government-hits-target-to-protectthose-most-at-risk. Accessed March 4, 2021.

27. Dey S. 41 lakh healthcare workers inoculated with Covid vaccine in India: The Times of India; 2021.

28. DAWN. PHC seeks registration for frontline health workers' vaccination. DAWN. 2021.

29. Hasan K. Covid-19: health care workers at govt facilities to get vaccine first. Dhaka Tribute. 2020.

30. DAWN. Nepalese doctor is God of Sight to poor: DAWN; 2010.

31. Qiao S, Tam CC, Li X. Risk exposures, risk perceptions, negative attitudes toward general vaccination, and COVID-19 vaccine acceptance among college students in South Carolina. medRxiv. 2020.

32. Grech V, Gauci C, Withdrawn AS. Vaccine hesitancy among Maltese Healthcare workers toward influenza and novel COVID-19 vaccination. Early Hum Dev. 2020;105213. doi:10.1016/j. earlhumdev.2020.105213

33. Wang J, Jing R, Lai X, et al. Acceptance of COVID-19 Vaccination during the COVID-19 Pandemic in China. Vaccines. 2020;8(3):482. doi: $10.3390 /$ vaccines 8030482

34. Dror AA, Netanel Eisenbach N, Taiber S. Vaccine hesitancy: the next challenge in the fight against COVID-19. Eur J Epidemiol. 2020;35 (8):775-779. doi:10.1007/s10654-020-00671-y

35. Lucia VC, Arati Kelekar A, Afonso NM. COVID-19 vaccine hesitancy among medical students. J Public Healt. 2020. doi:10.1093/ pubmed/fdaa 230

36. Thomas K. New Pfizer Results: coronavirus Vaccine Is Safe and 95\% Effective: The New York Times; 2020.

37. The Times of India. 23 die in Norway after receiving Pfizer Covid-19 vaccine, 13 were nursing home patients. Times India. 2021;1:45.

38. World Health Organization. [homepage on the Internet]. Who can take the Pfizer- BioNTech COVID-19 vaccine? Available from: https://www.who.int/news-room/feature-stories/detail/who-can-takethe-pfizer-biontech-covid-19-vaccine. Accessed: March 4, 2021.

39. News.cn [homepage on the Internet]. Nepal starts vaccination drive against COVID-19. Available from: http://www.xinhuanet.com/eng lish/2021-01/27/c_139701463.htm. Accessed March 7, 2021.

40. Fisher KA, Bloomstone SJ, Walder J, Crawford S, Fouayzi H, Mazor KM. Attitudes Toward a Potential SARS-CoV-2 Vaccine: a Survey of U.S. Adults. Ann Intern Med. 2020;173(12):964-973. doi:10.7326/M20-3569

41. Marcec R, Majta M, Likic R. Will vaccination refusal prolong the war on SARS-CoV-2? Postgrad Med J. 2021;97(1145):143-149. doi:10.1136/postgradmedj-2020-138903

42. Walder J. Vaccine hesitancy poses challenge for Nepal's campaign against Covid-19. The Kathmandu Post. 2021.

43. Ruiz JB, Bell RA. "Predictors of intention to vaccinate against COVID-19: results of a nationwide survey.". Vaccine. 2021;39 (7):1080-1086. doi:10.1016/j.vaccine.2021.01.010

44. Pradhan A, Olsson PE. Sex differences in severity and mortality from COVID-19: are males more vulnerable? Biol Sex Differ. 2020;11 (1):1. doi:10.1186/s13293-020-00330-7

45. Adams RJ. Improving health outcomes with better patient understanding and education. Risk Manag Healthc Policy. 2010;3:61. doi:10.2147/RMHP.S7500

46. Borg MA, Scicluna EA. Over-the-counter acquisition of antibiotics in the Maltese general population. Int J Antimicrob Agents. 2002;20 (4):253-257. doi:10.1016/S0924-8579(02)00194-2

47. Carrasco-Garrido P, Jiménez-García R, Barrera VH. Predictive factors of self-medicated drug use among the Spanish adult population. Pharmacoepidemiol Drug Saf. 2008;17(2):193-199. doi:10.1002/ pds. 1455 
48. Centers for Disease Control and Prevention. [homepage on the Internet]. Caring for someone sick. Available from: https://www. cdc.gov/coronavirus/2019-ncov/if-you-are-sick/care-for-someone. html. Accessed March 4, 2021.
49. University of California, San Francisco. [homepage on the Internet]. We thought it was just a respiratory virus. Available from: https:// www.ucsf.edu/magazine/covid-body. Accessed March 4, 2021.

\section{Publish your work in this journal}

Risk Management and Healthcare Policy is an international, peerreviewed, open access journal focusing on all aspects of public health, policy, and preventative measures to promote good health and improve morbidity and mortality in the population. The journal welcomes submitted papers covering original research, basic science, clinical \& epidemiological studies, reviews and evaluations, guidelines, expert opinion and commentary, case reports and extended reports. The manuscript management system is completely online and includes a very quick and fair peer-review system, which is all easy to use. Visit http://www.dovepress.com/testimonials.php to read real quotes from published authors.

Submit your manuscript here: https://www.dovepress.com/risk-management-and-healthcare-policy-journal 